\title{
Bibliographical Activity on the North and North West
}

Geraldine A. Cooke

THE AREA OF CONCERN FOR MY PAPER THIS AFTERNOON IS THE NORTH AND North West. North generally means that area of Canada north of the 6oth parallel; and, for the purposes of this paper, I have considered North West to be the northern portion of the four western provinces that lies north of the $53 \mathrm{rd}$ parallel.

For many years, bibliographical activity on the North in Canada has been synonymous with the Arctic Bibliography, ${ }^{1}$ which not only covered Canada, but the whole circumpolar region. However, as noted by Marie Tremaine ${ }^{2}$ in I967 and restated by Maret Martna ${ }^{3}$ in 1974, the literature on the North is very diverse and reflects a wide range of research and developmental activities. In recent years, the literature has grown at a rapid rate. Petroleum industry activity in the North has spawned a volume of literature, including pipeline proposals, arctic shipping proposals, transcripts of hearings examining environmental and socio-economic impacts, and biological and sociological studies undertaken by both those for and against the development. Add to that the literature on hydro-electric development, mining development, satellite observations, underwater research, town planning, municipal services, government structure, native peoples' landclaims, tourism, highway construction; the list could go on and on. Therefore, it is not surprising that no one agency or bibliography is able to keep pace with the literature on the Canadian North, and that several, more compact, regional bibliographies have emerged as continuing series..$^{4,5,6}$ No doubt others will appear, since there is no indication of a lessening of interest in our northern regions.

Bibliographical activity can range from completely annotated bibliographies to the briefest of listings, such as library accession lists. Also, as noted by Dorothy Ryder ${ }^{7}$ in her background paper for this meeting, the published catalogues of some libraries are valuable bibliographical tools. Bibliographical activity on the North and North West includes all types of compilations, and I will endeavour to identify them as I survey each region.

\section{The North in general}

For many years the major source of bibliographic information on the Cana- 
dian North has been the Arctic Bibliography. However, it ceased publication with volume 16 , which was published in 1975 and included the literature to I97I. The entire sixteen-volume set remains as a valuable tool for historic research, but it is somewhat cumbersome to use as there is no comprehensive author or subject index. This deficiency may be rectified if a proposal currently before funding agencies is accepted. Jointly sponsored by the Boreal Institute for Northern Studies at the University of Alberta and the Institute of Polar Studies at Ohio State University, the proposal involves a computerproduced kwIC index by author, title, and abstract number of all 108,723 entries in the Arctic Bibliography. The title kwIC index is to serve also as a subject index by using the significant words in each title. The data is to be compiled so that citations and abstracts can be added at a later date if additional funding is available. Though far from ideal, the computer indexing proposal would provide a valuable aid to the more efficient use of the Arctic Bibliography.

In addition to Arctic Bibliography, important reference material has been compiled in Recent Polar Literature ${ }^{8}$ and the Bibliography on Cold Regions Science and Technology (better known as the CRREL Bibliography). Recent Polar Literature has been published since 193I by the Scott Polar Research Institute in Cambridge, England as a supplement to their periodical, Polar Record. The CRrel Bibliography, produced by the us Army Corps of Engineers, contains many useful listings particularly with regard to northern technology and engineering. Both bibliographies continue to be valuable references for Canadian literature.

The Arctic Institute of North America plans to replace the Arctic Bibliography with the Arctic Science and Technology Information System (ASTIS) which is described as a 'multi-purpose automated bibliographic database'.. ${ }^{10} \mathrm{It}$ is to function as a library cataloguing system, an abstracting and indexing service, and an on-line information retrieval system. The system is being developed using the spires (Stanford Public Information Retrieval System) data management system at the University of Alberta Computing Centre. The on-line indexes maintained by the system will allow the database to be searched by title, author, geographic location, and subject. The subject and geographic headings are based upon the LC-type headings used in the Arctic Institute Library. The ASTI System is intended to produce book labels, a printed or microfiche catalogue, a current awareness bulletin, yearly printed bibliographies, and on-line searching services.

The Astis database is being designed to be used by more than one library, but for the immediate future it will be used only by the Arctic Institute Library. On-line searching services are to be provided initially to the members of the Arctic Petroleum Operators Association who are funding AsTis, and then to the general public through the established database wholesalers. Cod- 
ing of cataloguing for ASTIS commenced May I, I978. Thus the system is still in its early developmental stages.

Meanwhile, the publication of the Library Accessions ${ }^{11}$ of the Arctic Institute Library has resumed. The accessions list is arranged by subject and it includes listings of northern circumpolar literature, much of which deals with Canada.

The Scott Polar Research Institute Library in Cambridge, England maintains a card catalogue which includes indexing entries for its extensive periodicals holdings and analytic entries for monographs, particularly those from conference proceedings. The entries, which contain brief annotations and are filed by subject and region, are organized in a catalogue which is classified in accordance with the Universal Decimal Classification for Use in Polar Libraries. ${ }^{12}$ The catalogue has been published by G.K. Hall ${ }^{13}$ in nineteen volumes. The most useful volumes for Canadian literature are volume I6, which includes the entries coded $\left({ }^{*} 4 \mathrm{I}\right)$ to $\left({ }^{*} 48\right)$ for Canadian land areas, and volume 18 , which includes entries coded $\left({ }^{\star} 62\right)$ to $\left({ }^{\star} 626\right)$ for Canadian arctic waters.

The Centre for Northern Studies and Research at McGill University (founded in 1973 as a successor to the McGill Committee on Northern Research) produces the Bibliography of McGill Northern Research. ${ }^{14}$ It is the first publication in an Information Series and it provides a listing of all literature on northern subjects written by persons associated with McGill. Since McGill University has a long history of involvement with northern research, the publication is extensive and includes over I, 500 entries indexed by subject and region. Supplements to this bibliography are to be published at intervals.

The accessions lists of many libraries contain northern entries. Naturally, the most useful are those from libraries whose collections are specifically northern oriented. Accessions lists from the libraries of the Institute for Northern Studies, ${ }^{15}$ the Boreal Institute for Northern Studies, ${ }^{16}$ the Department of Indian Affairs and Northern Development library in Yellowknife, ${ }^{17}$ and the Arctic Institute ${ }^{11}$ are among the most informative. All are arranged by subject except that of the Boreal Institute, which is arranged by country, thus facilitating the identification of specifically Canadian material.

The Boreal Institute's Library Accessions List, which is compiled from annotated catalogue cards and includes entries prepared from cards received from the Scott Polar Research Institute Library, is now produced by computer with the aid of the SPIREs data management system at the University of Alberta. Thus a database of northern materials is being produced which will provide several interesting possibilities for future use, including the printing of regional bibliographies on demand and on-line searching of the entire database. 
The only current index available which deals exclusively with northern literature is the Northern Titles KW IC Index ${ }^{18}$ produced by the Boreal Institute for Northern Studies. Designed as a first step towards the bibliographic control of northern literature, it is a KWIC (KeyWord In Context) index of the authors (first one only) and titles or headlines of relevant articles in periodicals, government documents, and northern newspapers received by the Boreal Institute Library. Compiled since 1972 , it is now available as computer print-out or by on-line searching through QL Systems. It should be noted that the index is geared to be very current, with the issue for any one month being available by the 15 th of the next month. Therefore, minimal time is spent in editing and no attempt is made to conform to standard subject words. Many of the periodicals indexed are covered by other indexing and abstracting services (for example, Canadian Periodicals Index), but only articles relevant to the north are included in the KwIC Index. The Index is the only one known which includes material from northern and native newspapers. Since the index is computer produced, it is possible to obtain several auxilliary indexes from the database; for example, an index of native published newspapers, or an index of articles on the north from a specific journal.

Another KWIC index produced at the Boreal Institute is an index of newsclippings from selected southern Canadian newspapers. ${ }^{19}$ It is reproduced commercially by Micro Media Limited which also provides microfiche of the newsclippings (except for those of the Globe and Mail because of copyright difficulties).

It should also be mentioned that the Mackenzie River Drainage Basin Interprovincial Liaison Committee ${ }^{20}$ is in the process of compiling a bibliography of references relevant to the management of that river drainage basin. The entries for this database cover northern sections of the provinces of British Columbia, Alberta, and Saskatchewan, as well as a large portion of the Mackenzie District of the NWT and a small area in the southeast corner of the Yukon. A reference binder has already been compiled, and the Boreal Institute for Northern Studies has been involved in a project to identify, abstract, and prepare entries to be added to the CWA (Canada Water) database maintained by the Water Resources Documentation Centre of the Department of the Environment. To date over three hundred entries have been made during a trial period. Continuation of the project is currently awaiting confirmation of funding.

\section{Northwest Territories}

Although there is no bibliography for the entire Northwest Territories such as that for the Yukon, there are several specific regional bibliographies.

Interest in the high arctic islands area of Canada has increased greatly in recent years due to petroleum exploration activity in the area and the proposed Polar Gas Pipeline Project. The bibliography compiled by N. Merle 
Peterson entitled Ecology of the Canadian Arctic Archipelago: Selected References $^{4}$ had added significantly to the referencing of the literature on the region. Four volumes have been published to date, a fifth is in press, and volumes 6 and 7 are in preparation. Volume 6 is to be a listing of all unpublished material, whereas the other volumes cover the published literature on the plant and animal ecology of the area. Articles on human ecology, anthropology, archaeology, and sociology are included only if they deal with the use of renewable resources. Literature from the physical sciences is included if the subject is of obvious importance as an ecosystem factor. The entries are indexed by subject and geographic coordinates of the study area, and are extensively annotated. Additional literature on the arctic islands region is included in a bibliography compiled by G. Miller and J. Sefton. It lists unpublished government reports on the Arctic Islands pipeline route. ${ }^{21}$

Recent petroleum industry activity has also led to increased interest in the Mackenzie Delta region of the NwT. The Mackenzie Delta Bibliography ${ }^{22}$ of M.J. Jones remains as the main reference source for this area, although many reports compiled in recent years provide valuable supplements.

There are many subject-oriented bibliographies for the northern regions of Canada. Examples are ones dealing with sanitation, ${ }^{23,24}$ marine transportation, ${ }^{25}$ and bird populations. ${ }^{26}$ One of the most recent ones published is the Northwest Territories Community Bibliography. ${ }^{27}$ For years, references for particular communities had to be gleaned from many different sources. The bibliography provides a useful compilation of these references, listed by community.

In recent years three northern National Parks have been established, and there are plans for six more in the near future. Parks Canada has sponsored extensive compilations and reviews of the literature pertaining to the areas designated for National Parks. The bibliographies are being compiled by consultant firms under contract to Parks Canada. To date, for the NwT, bibliographies for Auyuittuq, ${ }^{28}$ and $\mathrm{Nahanni}^{29}$ National Parks are completed. There is also one on Baffin Island excluding Auyuittuq Park. ${ }^{30}$

Finally, lists of publications pertaining to specific research projects, such as the Polar Continental Shelf Project ${ }^{31}$ and Operation Hazen-Tanquary ${ }^{32}$ have been issued. In addition, there have been extensive literature reviews undertaken in conjunction with other major northern studies and projects which have been compiled in bibliographies, which, though not formally published, are available in many libraries across Canada. Time does not permit a detailed examination or listing of these, but examples are literature surveys for pipeline proposals and hydro-electric projects.

\section{The Yukon}

The Yukon is a smaller geographical area than the NWT, so it has been an easier task to compile a bibliography of the literature on this Territory. The 
Yukon Bibliography ${ }^{33}$ was initiated by J. Lotz under the auspices of the Department of Northern Affairs and Natural Resources. The compilation of a Yukon Bibliography Update 5 has been assumed as an ongoing project of the Boreal Institute for Northern Studies with financial assistance from the Library Services Division of the Yukon Territorial Government. The amount of literature on the Yukon is now such that an updating volume is published every two years. The Update to 1977 will be published towards the end of this year. The Yukon Bibliography Update to 1973 and all subsequent issues have been produced with the aid of a computer. Thus an extensive database on the Yukon has been established and is available for on-line searching through QL Systems.

Similar to that for the NWT, compilation of bibliographies and literature reviews on the National Parks areas within the Territory have been undertaken. An initial bibliography for Kluane National Park ${ }^{34}$ and a later, more comprehensive one ${ }^{35}$ are already available.

\section{Northern British Columbia}

There is no known bibliography pertaining specifically to northern British Columbia. However, the continuing 'Bibliography of British Columbia' ${ }^{36}$ by F.M. Woodward in each issue of B.C. Studies contains many relevant entries. Also, because some material that is written about the Yukon contains reference to northern British Columbia, the section ' $\mathrm{Pb}$ Neighbouring Territories: British Columbia' in each issue of Yukon Bibliography Update provides a partial bibliography for the northern regions of British Columbia.

\section{Northern Alberta}

The main bibliography pertaining to northern Alberta is the Alberta Oil Sands Index. ${ }^{37}$ Begun in the 1960 s by Imperial Oil Limited for Syncrude Canada Limited (then Cities Service Athabasca Limited) this bibliography contains listings relating to oil sands areas of northern Alberta. The responsibility for the bibliography was assumed by the Alberta Research Council in I97I; it is now undertaken by the Alberta Oil Sands Information Centre which was established in 1975 through a five-year grant from the Alberta Oil Sands Technology and Research Authority (AOsTRA). The Information Centre is part of the Oil Sands Research Centre, a division of the Alberta Research Council. The bibliography has undergone several format reorganizations and computer program rewritings. Originally only covering the Athabasca Oil Sands area, the Index now includes information on all oil sands in Alberta. To date over 4,00o documents have been indexed and about I,ooo are added each year. The Index is currently being converted to an on-line database available through SPIREs at the University of Alberta, and abstracts are being added to the listings. As well, the printed version /updated 
by quarterly supplements and cumulated annually) is being reorganized. ${ }^{38}$

Other bibliographies on northern Alberta include one on the socioeconomic and environmental effects of development of the Athabasca Oil Sands compiled by Susan Moysa and Betty Rost of the Alberta Environment Library. The bibliography contains over 800 entries. ${ }^{39}$ In addition, another of the Parks Canada sponsored bibliographies is available for Wood Buffalo National Park. ${ }^{40}$

\section{Northern Saskatchewan}

The Institute for Northern Studies at the University of Saskatchewan in Saskatoon has not only published several valuable directories for northern Saskatchewan, it has also published the Northern Saskatchewan Bibliography. ${ }^{6}$ This bibliography combines and updates two previously separate publications: Bibliography on Human Development in Northern Saskatchewan and the Annotated Bibliography on Eco-biology of Northern Saskatchewan. ${ }^{41}$ Each section of the bibliography is indexed by subject and geographic location. An update of this bibliography is currently in progress. The Annotated Bibliography of Geology in Saskatchewan, 1823-1970 ${ }^{42}$ has not been consolidated in the Northern Saskatchewan Bibliography, but it remains as a useful reference for the specific topic of geology and contains material pertaining to northern Saskatchewan. An initial bibliography has also been compiled for Prince Albert National Park, ${ }^{43}$ again under the sponsorship of Parks Canada.

\section{Northern Manitoba}

The Hudson Bay Lowlands Bibliography ${ }^{44}$ a product of the 1975 conference on the Hudson Bay Lowlands, provides a select listing of annotated references on the lowlands west of Hudson Bay stretching from Chesterfield Inlet in the north to the Nottaway river at the south end of James Bay.

Another useful source of bibliographical information on Northern Manitoba and Saskatchewan is the reports, particularly those containing lists of references, which were prepared for the Churchill River Study of $1975 .{ }^{45}$

\section{Conclusion}

No review of bibliographical activity in the North would be complete without mention of the Northern Libraries Colloquy Group. ${ }^{46}$ This international group of librarians and bibliographers has met since 1971, and a topic at each meeting is bibliographic control of the northern literature and international cooperation. To date progress has been slow, partly due to the informality of the group and other commitments of the members. A bibliographic committee has been formed with Garth Graham, Director of Information Resources of the Yukon, and Peter Anderson, Assistant Director of the Institute of Polar 
Studies in Ohio, as co-chairmen. ${ }^{47}$ In 1975 the group published a directory on the library resources in the northern hemisphere which cover polar and cold regions. ${ }^{48}$

As long ago as 1973, Garth Graham proposed an international network, International Northern Information Network $\left(\mathrm{IN}^{2}\right){ }_{1}^{49}$ to coordinate the bibliographical activities of the various circumpolar countries. Clearly, before we as Canadians can take part in any such a network, there is a need to coordinate activities and to define the responsibilites of the various Canadian institutes, government departments, and other organizations and individuals. As you may have gathered from the brief survey in this paper, there are many persons involved in bibliographical activity on the north. To a large extent, each goes his own way, sometimes drawing on the work of others and sometimes starting from scratch, blithely unaware that others have gone before. No doubt financial constraints will help to force the necessary cooperation, and meetings such as this one may help to focus attention on the problem. The Association of Canadian Universities for Northern Studies has already recognized the need for coordination and cooperation and has sponsored some meetings.

In addition, with the increasing use of computers to aid in the production of bibliographies, it is becoming possible to produce several bibliographies from the same database. Also, by merging several small regional bibliographies, it is possible to compile a complete bibliography with little additional human effort required.

Since preparing this paper, three publications have been released which should be mentioned. The first is the completing volume in the series Canadian Local Histories to 1950: A Bibliography ${ }^{50}$ prepared by William Morley. This third volume covers local history sources for Ontario and the Canadian North. In searching for items for the section on the Canadian North, it was found that there were few that were a local history of a settlement in the strict sense of the term, particularly when limited to those published prior to 1950 and exclusive of journal articles. Thus the author included histories of exploration for the area as being 'the valid local history of an area at a certain stage of that area's development.'

The second has been long awaited since a preliminary form was published in a series of issues of the Polar Record. The Exploration of Northern Canada, 500 to 1920: $A$ Chronology ${ }^{51}$ by Alan Cooke and Clive Holland is a valuable reference tool for historians and many others. In addition to the chronology, which gives details of the expeditions, there is a comprehensive bibliography, an index, maps, and a roster of members of the expeditions listed. The research for this important work was financially supported by the National Museum of Man.

The third and most recent publication, North of $60,{ }^{52}$ is not a bibliography per se. However, since it lists current and recently completed research proj- 
ects, including any publications to date resulting from those projects, it is a valuable listing for anyone interested in northern bibliography. This first issue of a series of publications covers research and studies undertaken in I975 and I976. Also, the data is to be converted to a machine-readable form and will be made available as a searcheable data base by the Canada Institute for Scientific and Technical Information.

From this brief survey, it is evident that bibliographical activity on the North and North West has flourished in recent years and that many institutes or agencies are now involved. The growth of literature on the Canadian North has prompted many new bibliographic endeavours and it is time that we, as librarians and bibliographers, begin to coordinate our efforts in order to produce the variety of comprehensive reference material that is now required.

My thanks to the many librarians and bibliographers who gave input to this paper. My special thanks to Geraldine Perry for compiling the list of references and to A.D. Cooke for editorial assistance.

\section{References}

I. Arctic Bibliography. Prepared by the Arctic Institute of North America with the support of government agencies in the United States and Canada. Montreal: McGill-Queen's Press, 1953-I975. I6v. (M. Tremaine, ed., v.I-I4; M. Martna, ed., v.15-I6).

2. Tremaine, M. 'The North in Canadian Bibliography.' Papers of the Bibliographical Society of Canada, vi (I967), pp.9-2I.

3. Martna, M. 'Regional Bibliography: The North.' In Proceedings of the National Conference on the State of Canadian Bibliography, Vancouver, Canada, May 22-24, 1974, pp.I4I-I52. Ottawa: National Library of Canada, 1977.

4. Peterson, N.M. Ecology of the Canadian Arctic Archipelago: Selected References. Ottawa: Department of Indian and Northern Affairs, 1974- .

5. Yukon Bibliography - Update 1963-1970. Compiled by C.A. Hemstock and G.A. Cooke. Edmonton: Boreal Institute for Northern Studies, University of Alberta, 1973. 420p. (Occasional Publication, 8-I).

Yukon Bibliography - Update to 1973. Compiled by C.A. Hemstock. Edmonton: Boreal Institute for Northern Studies, University of Alberta, 1975. 384p. (Occasional Publication, 8-2).

Yukon Bibliography - Update to 1975. Compiled by M.F. Ridge and G.A. Cooke. Edmonton: Boreal Institute for Northern Studies, University of Alberta, 1977.408p. (Occasional Publication, 8-3).

6. Dibb, S., ed. Northern Saskatchewan Bibliography. Saskatoon: Institute for Northern Studies, University of Saskatchewan, 1975. 8I p. (Mawdsley Memoir, 2).

7. Ryder, D.E. The Canadian West and the North: A Bibliographical Overview. Edmonton: University of Alberta Library, 1978. 13p.

8. Scott Polar Research Institute. Recent Polar Literature: Supplement to the Polar Record. Cambridge, England, I931- .

9. Bibliography on Cold Regions Science and Technology. Hanover, N.H.: Corps of Engineers, Us Army, Cold Regions Research and Engineering Laboratory, v.23, 1969- . 
Io. Communication from Ross Goodwin, May I5, 1978.

II. Arctic Institute of North America. Library Accessions. Montreal and Calgary, r948- .

I2. Roberts, B. Universal Decimal Classification for Use in Polar Libraries. $3 \mathrm{~d}$ rev. ed. Cambridge, England: Scott Polar Research Institute, 1976. I77p. (sPRI Occasional Paper, 2; FID, 552).

I3. The Library Catalogue of the Scott Polar Research Institute. Boston: G.K. Hall, I976. I9v.

14. Bibliography of McGill Northern Research 1887-1975. Montreal: Centre for Northern Studies and Research, McGill University, 1976. 92p. (Information Series, I).

I5. Institute for Northern Studies. Recent Acquisitions. Saskatoon, 1974- .

16. Boreal Institute for Northern Studies. Library Accessions list. Edmonton, 1971- .

17. Indian and Northern Affairs Library. Recent Acquisitions. Yellowknife, 1974-

I8. Northern Titles - KWIC Index. Edmonton: Boreal Institute for Northern Studies, University of Alberta, I972- .

I9. Boreal Institute Vertical Files on Northern Affairs: KWIC Index to Clipping Service on Microfiche. Toronto: Micro Media Ltd., I975- .

20. The Mackenzie Basin: Proceedings of the Intergovernmental Seminar held at Inuvik, NWT, June 24-27, 1972. Ottawa: Inland Waters Directorate, Environment Canada, 1973. I3Ip.

2I. Sefton, J. and G. Miller. The Arctic Islands Pipeline Route: A Bibliography of Unpublished Fisheries and Environment Canada Reports. Ottawa: Department of Indian and Northern Affairs, 1978. In press.

22. Jones, M.J., ed. Mackenzie Delta Bibliography. Ottawa: Northern Science Research Group, Department of Indian Affairs and Northern Development, 1969. 199p. (Mackenzie Delta Research Project, MDRP 6).

23. Heinke, G.W. Arctic Sanitary Engineering Bibliography: Preliminary Draft. Ottawa: Northern Science Research Group, Department of Indian Affairs and Northern Development, 1970. I38p.

24. Cameron, J.J. and D.W. Smith. Annotated Bibliography on Northern Environmental Engineering 1974-1975. Ottawa: Supply and Services Canada, 1977. 154p. (Economic and Technical Review Report, EPS 3-w P-77-6).

25. Katz, B.J. Arctic Petroleum Transportation Bibliography. Winnipeg: Natural Resource Institute, University of Manitoba, 1974. 123p.

26. Johnson, S.R. and others. The Birds of the Beaufort Sea: An Annotated Bibliography. Victoria: Beaufort Sea Project, Department of the Environment, 1975. 169p.

27. Lanari, R. Northwest Territories Community Bibliography. Ottawa: Supply and Services Canada, 1976. 79p.

28. A.D. Revill Associates. A Bibliography of the Literature Pertaining to Auyuittuq National Park on Baffin Island. Belleville, Ontario, 1975. 207p.

29. Addison, W.D. A Preliminary Annotated Bibliography of Nahanni National Park and the South Nahanni Watershed, NWT. Ottawa: Parks Canada, Department of Indian and Northern Affairs, 1974. 149p.

30. A.D. Revill Associates. A Bibliography of the Literature Pertaining to Baffin Island (except Auyuittuq National Park). Belleville, Ontario, 1975. 199p.

3I. Hobson, G.D. and J. Voyce. Polar Continental Shelf Project: Titles and Abstracts of Scientific Papers supported by PCSP. Ottawa: Information Canada, 1974- .

32. Hattersley-Smith, G. Bibliography of Operation Hazen-Tanquary, 1968-1972. Ottawa: Defence Research Board, Department of National Defence, 1972. $7 \mathrm{p}$. (Technical Note, 72-18). 
33. Lotz, J.R. Yukon Bibliography. Ottawa: Northern Coordination and Research Centre, Department of Northern Affairs and National Resources, 1964. 155p. (Yukon Research Project Series, I).

34. Paterson, L.A. Annotated Bibliography of Kluane National Park, Yukon Territory. Edmonton: Canadian Wildlife Service, 1972.4I p.

35. Scace and Associates Ltd. The Kluane National Park Area: An Initial Bibliography. Ottawa: Parks Canada, Department of Indian and Northern Affairs, 1975. 249p.

36. Woodward, F.M. 'Bibliography of British Columbia.' In B.C. Studies. Vancouver; University of British Columbia Press, I968- .

37. Alberta Research Council. Alberta Oil Sands Index, 1789-1977. Edmonton, 1977.

38. Radvanyi, H. Alberta Oil Sands Information Centre. Edmonton, 1978. I2p.

39. Moysa, S. and B. Rost. A Bibliography of the Athabasca Oil Sands, Fort McMurray, Alberta Area: Socio-economic and Environmental Studies. 1976 cumulated update and supplements. Edmonton, 1976- .

40. Scace and Associates Ltd. Initial Bibliography of Wood Buffalo National Park. Ottawa: Parks Canada, Department of Indian and Northern Affairs, 1974. 156p.

4I. Foster, T.W., ed. Annotated Bibliography on Eco-biology in Northern Saskatchewan. Saskatoon: Institute for Northern Studies, University of Saskatchewan, 1973. 9op.

42. Kupsch, W.O. Annotated Bibliography of Saskatchewan Geology 1823-1970. Regina: Geological Sciences Branch, Department of Mineral Resources, 1973.421p.

43. Scace and Associates Ltd. An Initial Bibliography of Prince Albert National Park. Ottawa: Parks Canada, Department of Indian and Northern Affairs, 1974. 69p.

44. Henley, T.J. and P.L. Eyler. Hudson Bay Lowlands Bibliography. Winnipeg: The Natural Resource Institute, University of Manitoba, I976. 82p.

45. Churchill River Study (Missinipe Probe). Final Reports. Saskatoon, I975. 29v.

46. Cooke, G.A. 'The Northern Libraries Colloquy: A Brief History.' Library Association of Alberta Bulletin, 5, no. 3/4 (1974), pp.ror-103.

47. Cooke, N. 'Sixth Northern Libraries Colloquy.' Polar Record, i8 (1977), pp. 612-613.

48. Corley, N.T. Polar and Cold Regions Library Resources: A Directory. Ottawa: Northern Libraries Colloquy, I975. IV.

49. Graham, G. Report to A.J. Kerr, Department of Indian and Northern Affairs, following the Third Northern Libraries Colloquy, 1973.

50. Morley, W.F.E. Ontario and the Canadian North. Toronto: University of Toronto Press, 1978. 322p. (Canadian Local Histories to I950: A Bibliography, v. 3)

51. Cooke, A. and C. Holland. The Exploration of Northern Canada, 500 to 1920: A Chronology. Toronto: The Arctic History Press, 1978. 549, 25p.

52. Rosenberg, G. North of 60: Current and Recent Research and Studies relating to Northern Social Concerns. Ottawa: Supply and Services Canada, 1978. 218p. (NSF 78-I) 